\title{
THE PROSOPOGRAPHY OF ENGLISH MONASTIC ORDERS AT THE DISSOLUTION: EVIDENCE FROM THE NATIONAL ARCHIVES ASSESSED
}

\author{
By David E. Thornton $\star$
}

\begin{abstract}
This paper evaluates a number of series of document at The National Archives as evidence for the prosopography of monastic orders in England and Wales during the second half of the 1530s. In particular, the testimony of the acknowledgments of the Oath of Supremacy in 1534 (TNA, E 25), the certificates of the suppression commissioners in 1536, the deeds of surrender from 1538-40 (TNA, E 322), and the various types of document which outline monastic pensions are assessed in so far as they record the identity and numbers of monks, regular canons and nuns at the time of the Dissolution. The paper demonstrates that, despite the importance of these various primary sources, none when taken alone completely and accurately describe the religious personnel of individual monasteries, and concludes with a call for a fresh examination and publication of the relevant documents.
\end{abstract}

Keywords: Dissolution; monastic pensions; religious personnel; prosopography; Reformation; Valor Ecclesiasticus; naming practices

The 1530s were, to say the least, a traumatic time for the religious orders in England and Wales. As Henry VIII and Thomas Cromwell vigorously pursued a succession of personally and financially inspired religious policies, the monks, regular canons, nuns and friars of the kingdom found themselves compelled in turn to denounce the authority of the Pope as head of the Church; to submit to the institutional and often rather explicit scrutiny of representatives of the royal government; and finally to surrender up their religious houses to the king, leave their cloisters and enter the brave new world of the Henrician Reformation. ${ }^{1}$ Many religious seem

$\star$ DAVID E. THORNTON is an Assistant Professor in the Department of History, University of Bilkent, Turkey.

${ }^{1}$ Geoffrey Baskerville, English Monks and the Suppression of the Monasteries (Henley-on-Thames, 1936); G.W. Bernard, 'The Dissolution of the Monasteries', in History, xcvi, 2011, pp. 390-409; G.W. Bernard, The King's Reformation: Henry VIII and the Remaking of the English Church (New Haven, CT, 2005); Francis Aidan Gasquet, Henry VIII and the English Monasteries: An Attempt to Illustrate the History of Their Suppression (London, 1893); Martin Heale, The Abbots and Priors of Late Medieval and Reformation England (Oxford, 2016), 309-53; David Knowles, The Religious Orders in England (3 vols, Cambridge, 1948-59), iii; A.N. Savin, English Monasteries on the Eve of the 
to have adapted to these developments relatively easily; for others, however, they proved to be difficult, stressful and, in some cases, fatal. ${ }^{2}$ The task of understanding the responses of the regular clergy to the events of 1534-40 is partly a matter of being able to identify the religious men and women in question, and this in turn is a matter of accessing the relevant documentation. The National Archives (TNA) houses a number of series of document that not only can be employed to tell the story of the Dissolution in general, but more specifically allow the historian to identify and enumerate the membership of the last generation of religious orders in England and Wales. ${ }^{3}$ These TNA documents are all the more important because the episcopal ordination lists, which otherwise are an essential source for prosopography of male religious, are no longer extant for over half the English dioceses for the late 1530s. ${ }^{4}$ However, as David Knowles and Neville Hadcock stated, 'From c.1534 onwards data are plentiful ... but the interpretation of these figures is often a matter of controversy'.

The main problems encountered when attempting to establish the identity and numbers of religious at the Dissolution can be illustrated easily by means of one, simple example. On 20 August 1534, the abbot of the Benedictine monastery of Pershore, Worcestershire, and 20 fellow monks, added their signatures to a document, now preserved at TNA, acknowledging that King Henry was the Supreme Head of the Church in England. ${ }^{6}$ By January 1540 however, Pershore Abbey had been dissolved and its brethren assigned pensions, commensurate with the status of the abbey itself and their relative seniority within the community. The pension arrangements for the former abbot and 14 ex-monks of Pershore are outlined in a number of documents at TNA. Table 1 presents the names of the monks of Pershore in exactly the same order that they occur both in the acknowledgment of supremacy and in one of the pension lists.

Dissolution (Oxford, 1909); G.W.O. Woodward, The Dissolution of the Monasteries (London, 1966); Joyce Youings, The Dissolution of the Monasteries (London and New York, 1971).

${ }^{2}$ On the possible psychological effects of these events, see P.A. Cunich, 'The Ex-religious in Post-Dissolution Society: Symptoms of Post-traumatic Stress Disorder?', in The Religious Orders in Pre-Reformation England, ed. James Clark (Woodbridge, 2002), 227-38.

${ }^{3}$ Aidan Lawes, 'The Dissolution of the Monasteries and Chantries: Sources in The National Archives', in Genealogists' Magazine, xxvii, 2003, pp. 483-91; Vanessa Harding, 'Monastic Records and the Dissolution: A Tudor Revolution in the Archives?', in European History Quarterly, xlvi, 2016, pp. 480-96.

${ }^{4}$ On ordination lists, my paper 'How Useful Are Episcopal Ordination Lists as a Source for Medieval English Monastic History?', in Journal of Ecclesiastical History, lxix, 2018, pp. 493-530.

${ }^{5}$ David Knowles and R. Neville Hadcock, Medieval Religious Houses: England and Wales (2nd edn, London, 1971), 47.

${ }^{6}$ TNA, E 25/102/6; Frederick Devon, 'Inventory of the Original Acknowledgments of the Royal Supremacy, made by Religious Houses, \&c., and Deposited in the Treasury of the Receipt of the Exchequer, temp. Hen. VIII', in Seventh Report of the Deputy Keeper of the Public Records (London, 1846), 279-306, 298.

7 TNA, E 315/245, f. 150; E 315/234, ff. 133r-136r; LP, xv. 30, 548. For a slightly different pension list, see Bodl., MS Tanner 343, p. 2. 
Table 1: The Monks of Pershore in 1534 and 1540.

\begin{tabular}{ll}
\hline \multicolumn{1}{c}{ TNA, E 25/102/6 (1534) } & \multicolumn{1}{c}{ TNA, E 315/234 (1540) } \\
\hline John Poletensis, abbot & John Stonywell, episcopus Politensis, abbot \\
John Fladbury, prior & John Sandyford, prior \\
Robert Cheltenham, subprior & John Hill, subprior \\
Richard Langley, infirmarer & James Wellys, Kitchener \\
John Bradwey, sacristan & Richard Pollen, almoner \\
James Broughton & Gilbert Gybbyns, infirmarer \\
Richard Mathon, chantor & William Hibbold, sacristan \\
Gilbert Abberton, cook & Thomas Hawkyns, cellarer \\
Thomas Peopleton & John Survyor \\
John Compton, almoner & John Glyn \\
Will Worcester, subsacristan & Thomas Bradley \\
Thomas Pershore, third prior & William Creyse \\
John Ledbury, custos capelle & Andrew Dudley \\
John Caddecroft & George Philips \\
Richard Alcester, chaplain & Thomas Heathe \\
Thomas Upton & \\
Will Hawkesbury, succentor & \\
Andrew Strensham & \\
George Evesham & \\
Thomas Walcott & \\
Richard Beerley & \\
\hline
\end{tabular}

Comparison of these two lists has led a number of scholars to conclude that not only had the size of the religious community at Pershore declined significantly from 21 to 15 - during the intervening five and a half years between the summer of 1534 and the early months of 1540 , but that also, judging from the names of the monks in the relevant TNA documents, the personnel of the abbey had changed completely, with the possible exception of the abbot. ${ }^{8}$ I will argue below that the latter conclusion at least is incorrect. The example of Pershore thus highlights a number of problems faced by historians interested in the prosopography of the final years of English and Welsh monasticism: did numbers decline as sharply as some evidence would suggest, and who exactly were the inmates of monasteries

\footnotetext{
${ }^{8}$ For example, Francis B. Andrews, 'Notes on Pershore Abbey at the Time of the Suppression', in Laudate, viii, 1930, pp. 148-57, 232-43, 155-7; Knowles and Hadcock, Medieval Religious Houses, 73.
} 
and nunneries at the time of the Dissolution? This paper will attempt to examine these issues, by drawing on documents preserved at TNA, with special reference to evidence concerning 20 male religious houses in the pre-Reformation Diocese of Worcester, ${ }^{9}$ and also, where that evidence is lacking, more broadly.

\section{From supremacy to surrender: sources and statistics}

The Henrician Reformation impacted variously upon the religious orders in England and Wales through a sequence of distinct phases between 1534 and 1540 . Each phase is associated with a particular set of documents, mostly preserved today at TNA, which to differing degrees facilitate our understanding of the prosopography of the last monks, canons and nuns in England and Wales. The sequence begins with the infamous story of Henry VIII's wish to divorce his wife Katherine of Aragon and marry Anne Boleyn that culminated in the so-called breach with Rome and the establishment of an independent 'Church in England', with the king as its supreme head and his chief minister, Thomas Cromwell, as vicegerent in spiritual matters. In the spring of 1534, an Oath of Succession was administered throughout the kingdom, requiring Henry's subjects to recognise Anne as queen and accept the succession of any offspring of their union. Around the same time, both secular and regular members of the clergy were required to take various versions of an oath acknowledging the king's supremacy and denying that any foreign power had or ought to have ecclesiastical or spiritual authority in the realm. Monasteries, along with other ecclesiastical institutions such as cathedral chapters, colleges of secular priests and hospitals, were visited between May/June 1534 and the early months of 1535 and their personnel were required to add their signatures to a document indicating that they had made the profession. ${ }^{10}$ The king's position was further enforced with the Act of Supremacy on 3 November 1534 . $^{11}$ The original documents of these institutional professions are now preserved at TNA as series E 25. ${ }^{12}$ According to the current TNA online catalogue, E 25 comprises 195 items, although six are described as 'missing in transfer' and two others are conventual seals without the associated documents. Of the extant documents, over half (66\%) are acknowledgments of the Oath of Supremacy by members of religious houses between June and December 1534 . The remainder include similar acknowledgments by members of various types of secular religious institutions, as well as 18 by individual bishops (which mostly date from the early months of 1535). Table 2 summarises the content of E 25 according to type of institution.

\footnotetext{
9 On which, see Thornton, 'How Useful'.

${ }^{10}$ Knowles, Religious Orders, iii. 173-81; Jonathan Michael Gray, Oaths and the English Reformation (Cambridge, 2013).

1126 Henry VIII, c. 1.

12 Devon, 'Inventory'; Foedera, Conventiones, Litterae, et Cujuscunque Generis Acta Publica, inter Reges Angliae et Alios quosvis Impeatores, Reges, Pontifices, Principes, vel Communitates, ed. Thomas Rymer (20 vols, 1704-35), xiv. 492-527; LP, vii, nos. 921, 1024, 1121, 1216, 1347, 1594, and viii, no. 31.
} 
Table 2: Summary of documents in TNA, E 25.

\begin{tabular}{lc}
\hline Type of institution & No. of documents \\
\hline Archbishop/bishop & 18 \\
Cathedral chapters (secular) & 6 \\
College of secular priests/canons & 24 \\
Hospital & 9 \\
Religious house & $124 \star \star$ \\
Synod & 1 \\
University & 1 \\
University college & 6 \\
(Missing in transfer) & 6 \\
\hline TOTAL & 195 \\
$\star$ Includes hospitals staffed by regular canons. & \\
$\star \star$ Includes two seals, with document missing in transfer.
\end{tabular}

In addition to these documents in $\mathrm{E} 25$, it is worth adding that very occasionally the signatures of monks or regular canons occur in oath books in which the secular clergy had subscribed against the jurisdiction within the kingdom of the bishop of Rome. $^{13}$

On the same day as the Act of Supremacy, the Reformation Parliament also passed the First Fruits and Tenths Act which gave the government new powers to tax the clergy in England and Wales. ${ }^{14}$ In order to determine the value of ecclesiastical benefices and institutions, a nationwide survey was established on 30 January 1535 , with commissions for each county sent to record the temporal and spiritual possessions of both secular and regular ecclesiastical bodies. The survey lasted until early 1536 and the end product was the various documents known collectively as the Valor Ecclesiasticus, including a (now incomplete) series of original returns, held at TNA, as well as summaries and later copies of the returns..$^{15}$ The Valor, though of vast interest in itself, is of less value for our present purposes, as it does not generally provide information about the religious personnel of monasteries. On the other hand, a second ecclesiastical survey, or 'visitation', was undertaken around the same time with the express purpose of examining the religious and moral state of the monastic orders specifically. Between July 1535 and February 1536, a number of royal officials visited most religious houses in England and Wales with a set of articles or instructions to be asked and also a series of follow-up injunctions (regulations) to which the visitors were permitted to add their own findings or 'compertes' (comperta).

\footnotetext{
${ }^{13}$ TNA, E 36/63; E 36/64; LP, vii, no. 1025 (395-8).

${ }^{14} 26$ Henry VIII, c. 3.

${ }^{15}$ The Valor documents form part of TNA series E 334. See Valor Ecclesiasticus temp. Henr. VIII. Auctoritate Regia Institutus, ed. John Caley and Joseph Hunter (6 vols, 1810-34).
} 
The progress and results of this royal visitation can be partly determined by examining the surviving letters written by the visitors to Cromwell, and also in a collection of documents known as the Compendium Compertorum. The extant comperta are preserved at TNA and record the findings made by two commissioners, Richard Layton and Thomas Legh, for religious houses in the Province of York and the Diocese of Coventry and Lichfield, the Diocese of Norwich, and a single set of findings for Chertsey Abbey, Surrey. ${ }^{16}$ There are entries for over 150 religious institutions, of which the vast majority (143) are monasteries, housing both male and female religious. For the latter, the names of individual inhabitants are given for 112 houses. However, these lists do not claim to be complete lists of personnel at the time of the visitation but only record those who had apparently confessed to certain sexual crimes, in some cases to more than one offence. ${ }^{17}$ In almost half the houses (45\%), this amounts to just one or two inmates, though in a few cases substantially more offenders are named. ${ }^{18}$

As the Valor had demonstrated not only the value of the Church as a whole but the relative values of individual ecclesiastical institutions, and as the royal visitation had seemingly highlighted the moral decay of the religious clergy, especially of those living in smaller monasteries, parliament passed the Act of Suppression in early $1536,{ }^{19}$ with the intention of dissolving all those houses worth less than £200 p.a. At this point only the superiors were offered pensions. Other brethren of suppressed houses would be given two options: to continue in religion by transferring to another, larger house of the same order, or to request a dispensation from monastic vows. Thus, with the decision to suppress the smaller houses taken, a new series of commissions was established, by county, between May and September 1536, to enquire into the situation at the houses earmarked for closure. This time, the commissioners had a fixed, simple list of criteria to examine ('articles of the instructions'), which included the number of religious persons at each house, how many were priests, and how many wished to have dispensations. The commissions for suppression sent reports to the newly created Court of Augmentations and a number of these 'certificates' or 'brief certificates' survive, again mostly at TNA. ${ }^{20}$

${ }^{16}$ TNA, SP 1/102, fos. 85-102; LP, x, no. 364.

${ }^{17}$ Anthony N. Shaw, 'The Compendium Compertorum and the making of the Suppression Act of 1536' (University of Warwick Ph.D. thesis, 2003); A.N. Shaw, 'The Compendium Compertorum and Associated Correspondence of the Royal Visitation: A Comparison between the Norwich Diocese Visitation and the York Province and Coventry and Lichfield Diocese Visitation, in the Period November 1535 to February 1536' (University of Warwick, MA dissertation, 1998); A.N. Shaw, 'The Northern Visitation of 1535/6: Some New Observations', in Downside Review, cxvi, 1998, pp. 279-99.

${ }^{18}$ A total of 21 monks of Selby Abbey are named, also 16 monks from Fountains Abbey and the same number of canons of Thurgarton Priory.

1927 Henry VIII, c. 28; Knowles, Religious Orders, iii. 304-17; Sybil Jack, 'The Last Days of the Smaller Monasteries in England', in Journal of Ecclesiastical History, xxi, 1970, pp. 97-124.

${ }^{20}$ TNA, DL 43/4/11; DL 43/5/7 (Lancs.); E 36/154/48-63 (Leics., Rutland and War.); SC 12/4/38 (Bucks. and Berks.); SC 12/33/27 (Hants., Wilts. and Gloucs.); SC 12/33/29 (Norfolk); SC 12/33/30 (Surrey); SP 5/3/128 (Sussex); see also BL, Cleop. E.IV, ff. 280r-284v, 288; BL, Harley MS 604, 
Table 3: Extant certificates of the suppression commissioners.

\begin{tabular}{|c|c|c|c|}
\hline County & Number & County & Number \\
\hline Berks. & 3 & Norfolk & 24 \\
\hline Bucks. & 8 & Rutland & 1 \\
\hline Gloucs. & $6+2^{\star}$ & Surrey $\star \star$ & 3 \\
\hline Hants. & 7 & Sussex & $7+1$ \\
\hline Hunts. & 5 & War. & 12 \\
\hline Lancs. & 5 & Wilts. & 9 \\
\hline
\end{tabular}

Leics.

8

$\star$ Two Bristol houses are treated separately from the rest of Gloucestershire.

$\star \star$ The certificate for Surrey is damaged and probably incomplete.

Table 3 summarises the surviving certificates according to county. ${ }^{21}$ For present purposes, it should be stressed that the extant certificates do not give the names of individual religious, only their numbers, except in one case. ${ }^{22}$

In the end, 243 out of 453 lesser monasteries were suppressed by the government from the summer of 1536 until the early months of 1537, with many houses being 'exempted'. ${ }^{23}$ The work of the suppression commissioners was interrupted during the autumn of 1536 and early 1537 by a series of rebellions in the north of the kingdom - the Lincolnshire Rising, the so-called Pilgrimage of Grace and the Cumberland Rising - which were in part a popular response to the suppressions as well as a product of wider social and economic grievances. ${ }^{24}$ The fact that many members

f. 102. For printed and/or calendared versions, see LP, x, no. 1191, xi, App. Ii; LP, xii/i, no. 1; F.A. Gasquet, 'Overlooked Testimonies to the Character of the English Monasteries on the Eve of Their Suppression', in Dublin Review, cxiv, 1894, pp. 245-77; A. Jessopp, 'The Norfolk Monasteries at the Time of the Suppression by Henry VIII', in Norfolk Antiquarian Miscellany, ii, 1883, pp. 450-63; Denys Cook, Sixteenth-Century England, 1450-1600 (London, 1980), 51-2; George Lipscomb, The History and Antiquities of the County of Buckingham (2 vols, London, 1847), passim; Youings, Dissolution, 166-7. I am grateful to Dr Paul Dryburgh, TNA, for his help with SC 12/4/38.

${ }^{21}$ Note also W.G. Clark-Maxwell, 'Buildwas Abbey: The Survey of 1536', in Transactions of the Shropshire Archaeological Society, xlvi, 1931-2, pp. 65-9. In addition, see TNA, SC 12/33/28 (date Feb. 1539): mendicant houses in Hampshire, Wiltshire and Gloucestershire. The similar certificate for houses in Yorkshire and Nottinghamshire, in BL, Cleop. E.IV, f. 300, would appear to be later in date as it relates to houses surrendered in 1538-9 and summarises the value of pensions assigned to the religious. A summary of the work of the suppression commissioners in 1536 is extant in a later copy: Cambridge, Corpus Christi College MS 111: Shaw, 'The Compendium Compertorum', $28-32$.

${ }^{22}$ The exception being the certificate for Huntingdonshire in BL, Cotton MS. Cleopatra E.IV, ff. 336r-340r.

${ }^{23}$ Sybil Jack, 'Dissolution Dates for the Monasteries Dissolved under the Act of 1536', in Historical Research, xliii, 1970, pp. 161-81.

${ }^{24}$ Knowles, Religious Orders, iii. 320-35; Anthony Fletcher and Diarmaid MacCulloch, Tudor 
of the religious orders were involved in these rebellions (whether of their own free will or otherwise) has often been seen as one reason why Cromwell and the king shortly thereafter shifted towards a new policy with the intention of dissolving all monasteries. As early as March 1537, Furness Abbey voluntarily surrendered to the government, and from November of that year until early 1540, all monastic and mendicant houses in England and Wales were similarly 'encouraged' to surrender by royal commissioners. Despite the supposedly voluntary nature of this phase, a further Act for the Dissolution of Abbeys was passed by parliament in 1539 to confirm that the property of any dissolved houses would become a possession of the government. ${ }^{25}$ The last monastery, Waltham Abbey, surrendered itself on 23 March 1540.

Table 4: Summary of documents in TNA, E 322.

\begin{tabular}{lc}
\hline Type of institution & No. of documents \\
\hline Bishopric & 2 \\
Chantry & 9 \\
College of secular priests & 17 \\
Free chapel & 5 \\
Guild/guild chapel & 3 \\
Hospital & 15 \\
Prebend & 4 \\
Rectory & 14 \\
Religious house: monastic & 163 \\
Religious house: mendicant & 51 \\
University college/hall & 9 \\
\hline
\end{tabular}

TNA series E 322 contains around 280 so-called deeds of surrender pertaining to various types of ecclesiastical institution. ${ }^{26}$ As Table 4 indicates, about threequarters of the items in E 322 are associated with religious houses, either monastic or mendicant, and date from the late 1530s. The majority of the remaining documents relate to secular ecclesiastical institutions that were dissolved in the 1540s and later. Like E 25, the deeds of surrender contain the signatures of individual religious, added either below the Latin text of the surrender or sometimes in the left-hand margin.

Finally, as well as being responsible for obtaining the surrender of monasteries, the commissioners of 1538-40 were also empowered to assign pensions to outgoing

Rebellions (6th edn, London and New York, 2016), 27-53; M.L. Bush, The Pilgrims' Complaint: A Study of Popular Thought in the Early Tudor North (Farnham, and Burlington, 2009).

${ }^{25} 31$ Henry VIII, c. 13.

${ }^{26}$ Foedera, ed. Rymer, xiv. 603-39; Joseph Hunter, 'The Old Catalogue of Original Surrenders Found amongst the Documents of the Late Augmentation Office', in Eighth Report of the Deputy Keeper of the Public Records (1847), 4-51. 
religious. Unlike in 1536, pensions were duly offered both to the rank-and-file members of houses and to superiors. Only the mendicant orders as a whole were not eligible because they were 'non-possessioner'. The extant records of monastic pensions are varied in type and date and are, again, preserved largely at TNA, though in this case scattered throughout many different classes of document. ${ }^{27}$ Broadly, they may be categorised as those that relate to the initial assignation of the pensions, and those that relate to the actual payment of the pensions subsequently. The commissioners prepared lists of the members of the now former monastery and their respective pensions. The pensions seem to have been assigned relatively soon after the surrender, often within a day or so. ${ }^{28}$ Subsequently, letters patent were issued describing the pension for an individual plus any additional monetary bonus and outlining the terms of payment, normally in two yearly instalments. These letters patent were copied or 'enrolled' into codices at the Court of Augmentations, ${ }^{29}$ and are usually dated a few weeks or months after the surrender. ${ }^{30}$

The value of individual pensions depended partly on the seniority of the individual ex-religious and partly on the wealth and size of his or her former house. Evidence for the actual payment of the pensions can be found in a variety of TNA series, though these documents are largely unpublished and relatively understudied. ${ }^{31}$ For example, C 115/89 is a codex recording the receipt of various types of payment, including monastic pensions, deriving from former religious houses in Staffordshire and Worcestershire in 1539, 1540 and 1541. We see, for instance, that the ex-monks of Pershore received their half-yearly pensions on 28 April 1540 and 9 January 1541. Pensions were paid either directly to the individual pensioner or 'by the hands of' a third party or agent, and continued to be paid as long as the former religious lived and did not accept some sort of benefice. Thus, E 314/26-32 contain the receivers' vouchers for payments, including half-yearly monastic pensions, from the later years of Henry VIII and especially from the reign of Edward VI and the first year of Mary. These vouchers were signed by the former religious or by his/her agent. They have been pasted into separate volumes and arranged by county and to some extent by religious house. Furthermore, in the 1550s a number of commissions were established to determine the current state of pensions and other annuities associated with former religious houses: who was still being paid, had they sold their pensions to another person, and were payments in arrears? ${ }^{32}$

\footnotetext{
${ }^{27}$ On pensions, see Lawes, 'The Dissolution,' 487-9. TNA, E 315/232-5; E 315/244-7; E 314/53; E 314/77; E 101/76/27-9.

${ }^{28}$ For example, Fountains Abbey was surrendered on 16 November 1539 and the warrant in E 314/53 is dated two days later.

${ }^{29}$ TNA, E 315/233-4; LP, xv, no. 1032 (542-55).

${ }^{30}$ Thus, for Fountains, see TNA, E 101/76/27 and E 315/234, f. 283, both dated 1 March 1540.

${ }^{31}$ Margaret McGlynn, 'The Payment of Pensions to the Ex-religious of Tudor Bedfordshire', in Midland History, xxxii, 2007, pp. 41-67, draws on TNA, LR 6/75/1-12, LR 6/76/1-14 and LR $6 / 77 / 1$, to analyse the payment of pensions to former religious of Bedfordshire in the 1540 s and 1550 s.

${ }^{32}$ TNA, E 101/76/11-25, 37; E 101/603/19; E 36/59. See A.G. Dickens, 'Edwardian Arrears in
} 


\section{Coverage and comprehensiveness of the sources}

How comprehensive are these various groups of documents for studying the prosopography of the monastic orders in the second half of the 1530s? As should be apparent from the discussion above, with the exception of the pension lists and related documents, most categories of surviving document pertinent to this study are far from comprehensive. Knowles and Hadcock estimated that there were as many as c.850 religious houses in England and Wales in around $1530,{ }^{33}$ in which case the number of surviving acknowledgments of the Oath of Supremacy in E 25 (124 by religious houses) and the number of deeds of surrender in E 322 (214) fall well below the possible total. The figure for E 25 can be partly explained in terms of the religious orders represented, and also the geographical distribution of the houses in question. Conspicuous by their absence are the mendicant orders as a whole and the 'exempt' orders such as the Cistercians and Premonstratensians, except for two Carthusian priories (London and Sheen). Only three houses of female religious occur in E 25, all lacking any signatures. Even for those orders that are represented, especially the Benedictines and Augustinian canons, many houses are not recorded.

Table 5: Religious houses by order in TNA, E 25.

\begin{tabular}{lc}
\hline Religious order & No. of documents \\
\hline Bonhommes & 1 \\
Carthusians & $3(=2)$ \\
Augustinian Canons & 78 \\
Benedictine monks & 38 \\
Trinitarians & 1 \\
Nuns & 3 \\
\hline TOTAL & 124 \\
\hline
\end{tabular}

A further explanation for the relatively small number of E 25 documents becomes apparent if we analyse them geographically. Acknowledgments by members of religious houses in only 19 English counties survive in E 25 and a mere four counties in Wales.

Furthermore, even for those counties covered in E 25, not all monasteries are represented in the surviving series (see Table 6). Thus, for the Diocese of Worcester, which comprised Worcestershire, much of Gloucestershire and part of Warwickshire, only 12 of the 20 male religious houses occur in E 25, and just one nunnery (with no signatures, of course).

Augmentations Payments and the Problem of the Ex-religious', in EHR, lv, 1940, pp. 384-418. Also see TNA, E 164/31, along with BL, Add. 8102.

${ }^{33}$ Knowles and Hadcock, Medieval Religious Houses, 494. 
Table 6: Religious houses by county in TNA, E 25.

\begin{tabular}{lc}
\hline County & No. of documents \\
\hline Beds. & 4 \\
Brecon & 1 \\
Bucks. & 4 \\
Carm. & 1 \\
Corn. & 4 \\
Devon & 5 \\
Essex & 6 \\
Gloucs. & 7 \\
Herts. & 2 \\
Hunts. & 3 \\
Kent & 10 \\
Leics. & 5 \\
\hline
\end{tabular}

\begin{tabular}{lc}
\hline County & No. of documents \\
\hline Lincs. & 14 \\
London & 6 \\
Monm. & 4 \\
Nhants. & 4 \\
Norfolk & 17 \\
Oxon. & 5 \\
Pemb. & 3 \\
Som. & 8 \\
Suffolk & 5 \\
War. & 3 \\
Worcs. & 3 \\
\hline TOTAL & 124 \\
\hline
\end{tabular}

It seems more likely that many acknowledgments of the supremacy have been lost since 1534 and thus are not extant in E 25, rather than that many religious houses were simply not required to subscribe. Indeed, in his Mitred Abbies (1718-19), Browne Willis listed at least six additional monasteries whose members took the oath: the Benedictine house at Hatfield Regis; the Gilbertines at Chicksands, Hitchin and North Ormsby; and the Cistercians at Bordesley and Roche. ${ }^{34}$ Willis also states that the abbots of Abingdon and Westminster, both Benedictine houses, subscribed to the supremacy, though he does not mention whether the brethren did so. ${ }^{35}$ The acknowledgment by the monks of Hatfield Regis, Essex, does in fact survive but was incorrectly assigned to TNA series E $322 .^{36}$ The occurrence of two Cistercian abbeys and three Gilbertine priories according to Willis is somewhat anomalous since, as stated above, no houses of those orders are attested in the surviving E 25 documents; and Roche Abbey is especially odd, as that house was located in Yorkshire.

The surviving deeds of surrender are more generally representative than the acknowledgments of the Oath of Supremacy, though as only the deeds for a total of 214 religious houses survive in the series, it is also far from complete. For the Diocese of Worcester, the deeds of surrender of a mere three out of 20 male religious houses are presented, and no nunneries. There exist a total of 27 deeds for female religious houses in E 322, along with 10 Gilbertine double-houses. However, of

\footnotetext{
${ }^{34}$ Browne Willis, An History of the Mitred Parliamentary Abbies, and Conventual Cathedral Churches (2 vols, London, 1718-19), ii. 2, 79, 94, 121, 259, 283.

${ }^{35}$ Ibid., i. 8, 207.

${ }^{36}$ TNA, E 322/96. Note also for Ewenny Priory, Glam., the acknowledgment of the supremacy is in BL, Cleop. F.VI. 204, dated 11 Sept. 1534.
} 
Table 7: Religious houses by order in TNA, E 322.

\begin{tabular}{|c|c|c|c|}
\hline Order & No. of documents & Order & No. of documents \\
\hline Augustinian canons & 47 & Praemonstratensians & 9 \\
\hline Benedictines & 43 & Trinitarians & 3 \\
\hline Bonhommes & 1 & Austin friars & 10 \\
\hline Carthusians & 6 & Carmelite friars & 10 \\
\hline Cistercians & 31 & Crutched friars & 2 \\
\hline Cluniacs & 4 & Dominicans & 13 \\
\hline Fontevrault & 1 & Franciscans & 16 \\
\hline Gilbertines & 18 & TOTAL & 214 \\
\hline
\end{tabular}

these 37 houses, the signatures of the nuns are mostly lacking: only eight deeds contain the names of the relevant female religious and in one case (Shaftesbury) only the abbess signed, and in another (Tarrant Kaines) the nuns' names are written in a single hand (see below). Of the Gilbertine double-houses, three have the signatures of both canons and nuns, the rest of canons only. Unlike in E 25, most monastic and mendicant orders are represented.

The relatively restricted geographical coverage of the surviving Compendium Compertorum and certificates of the commissioners of suppression in 1536 has already been mentioned above, and, of course, in the case of the 'brief certificates', only the lesser monasteries earmarked for suppression were visited and the relevant information recorded. We are, however, on firmer ground when turning to the surviving sources relating to monastic pensions: these are certainly not limited by geographical coverage or religious order, except for the fact, already noted, that the friars did not receive pensions. However, even here, there are some gaps. ${ }^{37}$ As mentioned above, for the lesser monasteries suppressed in 1536, only the superior received a pension. Furthermore, members of those monasteries which had fallen into the king's hands by the attainder for treason of its superior were not guaranteed pensions. ${ }^{38}$ These include those houses implicated in the northern rebellions of 1536-7, such as Jervaulx, Kirkstead and Whalley, for all of which there is also no surviving acknowledgment of the supremacy and, of course, no deed of surrender. Similarly, although the last abbot of Glastonbury had resisted voluntary surrender and was duly executed along with some of his brethren, those monks willing to depart were apparently to be given pensions, but they do not occur in pension lists until the commissions of Mary's reign, ${ }^{39}$ by which time many had no doubt died.

\footnotetext{
${ }^{37}$ G.A.J. Hodgett, 'The Unpensioned Ex-religious in Tudor England', in Journal of Ecclesiastical History, xiii, 1962, pp. 195-202.

${ }^{38}$ But note Knowles, Religious Orders, iii. 404-5.

${ }^{39}$ LP, xiv/i, no. 232; J. H. Bettey, The Suppression of the Monasteries in the West Country (Gloucester, 1989); Knowles, Religious Orders, iii. 404.
} 


\section{Monastic personnel: names and numbers}

With the exception of the pension lists, therefore, the various categories of TNA document discussed above are far from comprehensive in terms of either the geographical range or the religious orders covered by the extant items, or both. Any attempt to study the prosopography of English and Welsh monasteries at the Dissolution must take this important fact into account. A further problem when attempting to reconstruct the membership of monasteries is that in some cases, as we have seen with Pershore Abbey, there would appear to have been an almost total change in personnel between 1534 and 1538-40. The only name recorded for both 1534 and 1540 is that of Abbot John, who was bishop in partibus of Pulati (in Albania) and whose surname, Stonywell, was supplied in the 1540 pension list. ${ }^{40}$ None of the other 14 names of pensioners in 1540 - of whom nine were still receiving pensions in Mary's reign - occur in the acknowledgment of the Oath of Supremacy. Now, the relative order of names in such lists of religious - what I have termed elsewhere "conventual lists" ${ }^{41}$ - was important because usually, in late medieval England, monks (and canons) were recorded according to seniority; that is, according to the time since admission, with the superior and senior obedientiaries named first. This tradition of ordering by seniority appears to have been retained, though not always strictly, even after the Dissolution of the Monasteries. Thus, for Pershore, if we reorganise the table without changing the relative order of the names at all, and match up forenames, we see that the two lists do in fact correspond, with a few inevitable gaps, as shown in Table 8.

This matching is aided by the fact that the less common forenames James (Jacob), Gilbert, Andrew and George each occur once in both lists. Thus, for example, if the name James Broughton of 1534 is aligned with James Wellys of 1540, we see he is preceded in each case by a John and succeeded immediately by a Richard and then a Gilbert. All the names of the 15 pensioners of 1540 can be matched with one of the signatories of 1534 in this way, without any alteration to the relative order of forenames in either document. This would suggest that the 15 ex-monks of 1540 had in fact all been members of the community back in 1534 but had apparently changed their surnames. ${ }^{42}$

This change in surname was probably a return by the ex-monks of Pershore to using their hereditary family surnames which they had dropped when admitted to the abbey. It has long been recognised by historians that most monks and regular canons in later medieval England assumed a new surname on admission, which I will call 'monastic bynames' hereafter. These bynames were generally toponymic in character

\footnotetext{
${ }^{40}$ On Abbot John, see James G. Clark, 'Stonywell [Stanwell], John (d. 1553), Abbot of Pershore', in $O D N B$

${ }^{41}$ Thornton, 'How Useful'.

${ }^{42}$ Some 14 of the 15 ex-monks are recorded having received their pensions in TNA, C 115/89, on 28 April 1540 and 9 January 1541: only John Hill (prev. Bradwey) is missing. Here however, we also find the quondam abbot William Compton (abb. 1504-26), said to have received pensions on 10 Oct. 1540 and 2 January 1541.
} 
Table 8: The monks of Pershore in 1534 and 1540, matched by forename.

\begin{tabular}{ll}
\hline \multicolumn{1}{c}{ TNA, E 25/102/6 (1534) } & \multicolumn{1}{c}{ TNA, E 315/234 (1540) } \\
\hline John Poletensis, abbot & John Stonywell, episcopus Politensis, abbot \\
John Fladbury, prior & John Sandford, prior \\
Robert Cheltenham, subprior & \\
Richard Langley, infirmarer & \\
John Bradwey, sacristan & John Hill, subprior \\
James Broughton & James Wellys, kitchener \\
Richard Mathon, chantor & Richard Pollen, almoner \\
Gilbert Abberton, cook & Gilbert Gybbyns, infirmarer \\
Thomas Peopleton & \\
John Compton, almoner & \\
William Worcester, subsacristan & William Hibbold, sacristan \\
Thomas Pershore, third prior & Thomas Hawkyns, cellarer \\
John Ledbury, custos capelle & John Survyor \\
John Caddecroft & John Glyn \\
Richard Alcester, chaplain & \\
Thomas Upton & Thomas Bradley \\
William Hawkesbury, succentor & William Creyse \\
Andrew Strensham & Andrew Dudley \\
George Evesham & George Philips \\
Thomas Walcott & Thomas Heathe \\
Richard Beerley & \\
\hline & \\
\hline
\end{tabular}

and it has been assumed that they indicate the place of birth or recent origin of the men in question. ${ }^{43}$ Furthermore, shortly before 1500 , some monks assumed bynames derived from saints' names and a very small number took on surnames that were Christian virtues. The practice of taking on a monastic byname on admission seems to have been followed largely by members of male monastic orders: the evidence for the names of late medieval female religious - which are less frequently recorded, of course - would suggest that they did not follow this practice, and the same can be said for the friars. By the time of the Dissolution, and certainly by 1538-40, many monks and canons appear to have reverted to using their family surnames. In the case

\footnotetext{
${ }^{43}$ For some comments on monastic bynames, see Knowles, Religious Orders, ii. 231; Joan Greatrex, The English Benedictine Cathedral Priories: Rule and Practice, c.1270-1420 (Oxford, 2011), 42-6; Barbara F. Harvey, Living and Dying in England, 1100-1540: The Monastic Experience (Oxford, 1993), 75-6. I hope to explore this subject in detail elsewhere.
} 


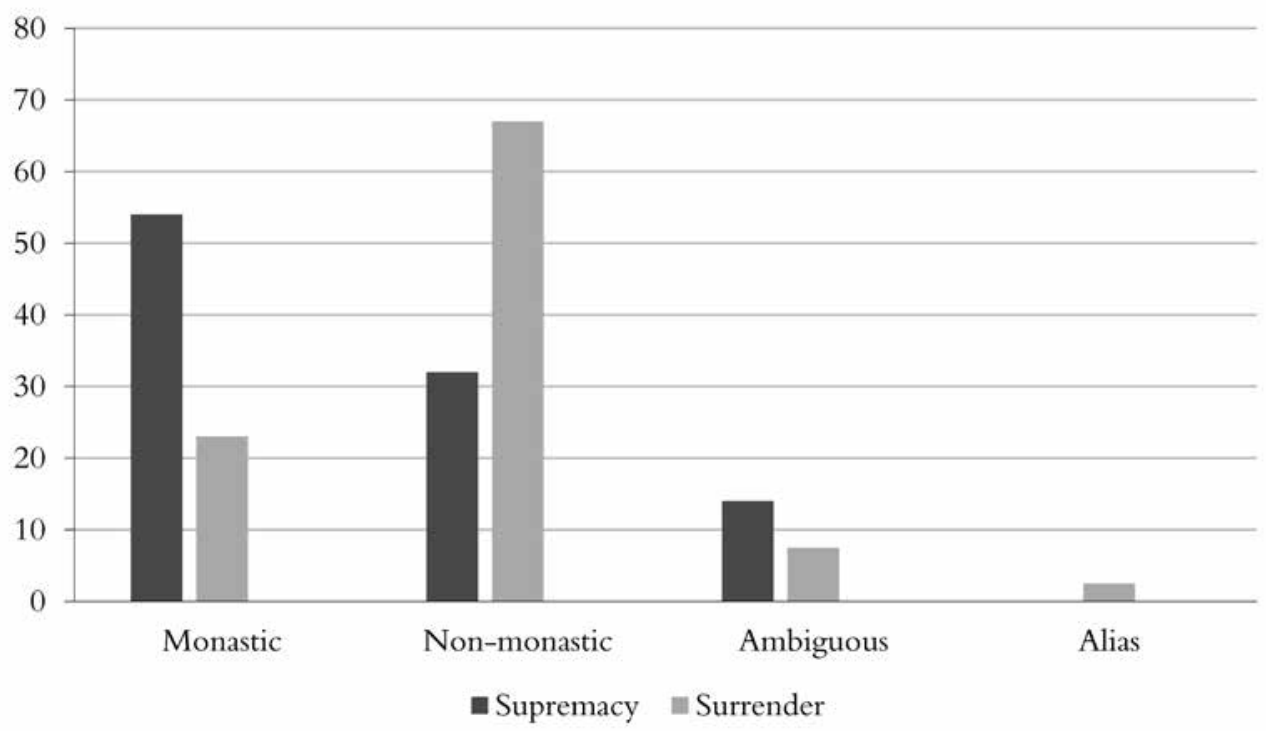

Figure 1: Comparison of surname types (by house) in 1534 and at surrender (\%).

of Pershore, this inference is reflected by the fact that, in 1534, all 21 monks bore toponymic surnames, whereas following the dissolution of the abbey six years later, only five pensioners had toponymic surnames (Bradley, Dudley, Stonywell, Sandford and maybe Wells) and a further three bore topographical surnames (Heath, Hill and maybe Glyn), the rest with patronymic, occupational and French surnames, which is a more typical distribution of surname types.

The decision to resume using the family surname, often undertaken by members of a former religious community as a whole, as at Pershore, rather than individually, was certainly not universal, yet nor was it extremely rare. While I have not attempted an in-depth and comprehensive analysis of surname patterns among former religious c.1540, some preliminary comments are possible here. An examination of the predominant surname type by religious house in E 25 would suggest that for approximately $54 \%$ of monasteries in that series most of the respective brethren bore monastic bynames (toponyms, saints' names or virtue names) in 1534, with a further $14 \%$ where about half the brothers in each house had monastic bynames (what I term 'ambiguous' here). On the other hand, for the deeds of surrender in E 322, in only $23 \%$ of religious houses did monastic bynames predominate. In as many as $67 \%$ of monasteries, the majority of brethren bore various other types of surname (occupational, descriptive, etc.). This pattern of change from 1534 to c.1538-40 is illustrated in Figure 1.

The graph does demonstrate that even by 1534, there was a significant proportion of monasteries in England and Wales where the majority of monks and canons did not bear traditional monastic bynames (toponyms or saints' names). However, there was clearly a marked shift away from this type of surname by $1538-40$ when most houses were surrendered. 
Table 9: Surnames of male religious in the Diocese of Worcester, c.1538-c.1540.

\begin{tabular}{|c|c|c|}
\hline House & Date range & Surnames \\
\hline Bordesley & $1538-56$ & Non-monastic \\
\hline Bristol OSA & $1539-56$ & Monastic \\
\hline Bristol Gaunts & $1539-40$ & Monastic \\
\hline Cirencester & $1339-56$ & $\begin{array}{l}\text { Non- } \\
\text { monastic }\end{array}$ \\
\hline Evesham & $1540-56$ & Monastic \\
\hline Gloucester OSB & $1538-56$ & Monastic \\
\hline Great Malvern & $1540-56$ & Monastic \\
\hline Hailes & $1539-56$ & $\begin{array}{l}\text { Non- } \\
\text { monastic }\end{array}$ \\
\hline
\end{tabular}

\begin{tabular}{|c|c|c|}
\hline House & Date range & Surnames \\
\hline Halesowen & 1538 & Monastic \\
\hline Kingswood & 1538 & $\begin{array}{l}\text { Non- } \\
\text { monastic }\end{array}$ \\
\hline Llanthony II & $\begin{array}{l}1538 \\
1538-56\end{array}$ & $\begin{array}{l}\text { Mixed } \\
\text { Monastic }\end{array}$ \\
\hline Pershore & $1540-56$ & $\begin{array}{l}\text { Non- } \\
\text { monastic }\end{array}$ \\
\hline Tewkesbury & $1539-56$ & Monastic \\
\hline Winchcombe & $1539-56$ & $\begin{array}{l}\text { Non- } \\
\text { monastic }\end{array}$ \\
\hline Worcester & $1540-56$ & Monastic \\
\hline
\end{tabular}

More detailed examination and comparison of monastic personnel would support this suggestion. Thus, of the 24 male monastic houses that occur both in TNA series E 25 and in E 322, members of at least five (20\%) appear to have changed their surnames (Bardney, Huntingdon Priory, Leicester OSA, Notley and Ulvescroft), and in one case, Dover Priory, the ex-monks are listed with two surnames (surname plus alias). This latter use of surname plus an alias can also be found in two other deeds of surrender in E 322 - Combe and Rievaulx abbeys, both Cistercian - and a brief survey of pension lists reveals aliases used for at least one other Cistercian house (Forde) and five former Benedictine abbeys (Bury St Edmunds, Crowland, Hyde, Peterborough and Ramsey). My own detailed study of the prosopography of 20 male monastic houses in the Diocese of Worcester demonstrates that, of the 15 houses which survived until the final phase of the Dissolution, the brethren of six (40\%) are probably recorded with familial (that is, non-monastic) surnames in the relevant deeds of surrender and/or pension documents, as shown in Table $8 .^{44}$

The evidence cited above indicates that there certainly was a change in the distribution of surnames among members of English monastic orders in the late 1530s. This pattern does not, I think, necessarily indicate a wholesale change in surnaming among monks and canons, but rather is a reflection of the fact that many male religious, on voluntarily surrendering to the royal commissioners and returning to the secular world, choose to resume using their hereditary, family surnames. I suspect further detailed analysis will reveal differences between religious orders and

${ }^{44}$ Thornton, 'How Useful'. 
perhaps even geographically. For instance, some orders, such as the Carthusians, did not necessarily assume toponymic surnames as readily as others. Furthermore, Cistercians in particular appear to have resumed using their family surnames in larger numbers than did, say, the Benedictines. ${ }^{45} \mathrm{~A}$ more detailed analysis of the data, including a breakdown by region or religious order, would help clarify these suggestions, but for present purposes we may conclude that by the time of the final dissolutions perhaps as many as over half of male religious had ceased using the monastic bynames with which they will have been recorded in earlier documents. As we have seen in the case of Pershore Abbey, this renders the task of identifying the individual monks and canons in the deeds of surrender and pension lists all the more difficult. Indeed, the solution offered for Pershore can go some way to resolving the problem, ${ }^{46}$ but it is not certain whether it would be quite as neat and clear-cut in all instances.

Turning from the task of identifying individual religious in the relevant TNA documents, a further problem, also highlighted by the Pershore Abbey case study, is the size of religious communities in England and Wales at the time of the Dissolution and the associated matter of how accurate or complete are the various lists of monastic personnel recorded in 1534 and later. Historians have generally concluded that the 1530s witnessed a decline in the size of the monastic population as a whole. ${ }^{47}$ The suppression of the smaller monasteries in 1536 certainly did encourage many religious to seek capacities, thus reducing total numbers to some extent, but there is evidence that even the larger, wealthier abbeys housed reduced communities by the time of their eventual surrender in 1538-40. Thus at Pershore Abbey the number of brethren had apparently fallen from 21 in 1534 to 15 by 1540. These conclusions are largely based upon the testimony of the various TNA documents discussed in this paper. Our ability to understand this apparent decline in the monastic demography depends partly on how accurately the relevant documents reveal the numbers of religious at individual houses at particular times.

On the face of it, the documentation does support the general assumption that numbers of religious were indeed falling during the 1530s. Thus Table 10 compares data for the 12 religious houses in the Diocese of Worcester for which acknowledgments of the supremacy survive in TNA series E 25 with the numbers of monks or canons of the same houses who later received pensions. Overall, the pattern would confirm that (of decline) seen at Pershore Abbey. Only one monastery (Tewkesbury) appears to have increased in size between 1534 and the granting of pensions; the rest experienced a drop in numbers. Indeed, evidence that the decline in the size of religious communities had started early may be implied if

\footnotetext{
${ }^{45}$ On the Cistercians, see David E. Thornton, 'Stability or Mobility? Movement between Cistercian Houses in Late Medieval England and Wales', in Citeaux: Commentarii Cistercienses (forthcoming). ${ }^{46}$ For a similar analysis for the last canons of Cirencester, see Thornton, 'How Useful', 519-20.

${ }^{47}$ For example, Knowles and Hadcock, Medieval Religious Houses, 488-94; Josiah Cox Russell, 'The Clerical Population of Medieval England', in Traditio, ii, 1944, pp. 177-212.
} 
Table 10: Numbers of brethren at monasteries in the Diocese of Worcester, 1534 and c.1540.

\begin{tabular}{lcc}
\hline House & Supremacy & Pension \\
\hline Bristol OSA & 19 & 12 \\
Bristol Gaunts & 5 & 4 \\
Cirencester & 21 & 17 \\
Gloucester OSB & 36 & 14 \\
Little Malvern & 8 & 1 \\
Llanthony & $23+5$ & 24,25 \\
Pershore & 21 & 15 \\
Studley & 9 & 1 \\
Tewkesbury & 38 & 39 \\
Warwick OSA & 2 & 1 \\
Winchcombe & 25 & 18 \\
Worcester OSB & 41 & 18 \\
\hline
\end{tabular}

Table 11: Number of brethren at religious houses in 1534 and 1536.

\begin{tabular}{|c|c|c|c|}
\hline House & County & 1534 & 1536 \\
\hline Beeston & Norf. & 5 & 3 \\
\hline Buckenham & Norf. & 11 & 5 \\
\hline Coxford & Norf. & 10 & 3 \\
\hline Horsham & Norf. & 7 & 4 \\
\hline Kirby Bellars & Hunts. & 10 & 9 \\
\hline Owston & Hunts. & 12 & 7 \\
\hline Pentney & Norf. & 14 & 9 \\
\hline Snelshall & Bucks. & 4 & 3 \\
\hline Stonely* & Hunts. & 7 & 7 \\
\hline Studley & War. & 9 & 9 \\
\hline Thetford & Norf. & 7 & 1 \\
\hline Ulvescroft & Hunts. & 10 & 9 \\
\hline Warwick OSA & War. & 2 & 4 \\
\hline Wroxall & War. & N/A & 6 \\
\hline Weybourne & Norf. & 2 & 2 \\
\hline
\end{tabular}


we compare the number of signatories to the supremacy in 1534 with numbers of religious reported in the brief certificates of the commissioners of suppression two years later. As indicated above, neither set of documents is comprehensive, though both do cover some counties in common. Data survives for fifteen houses and is summarised in Table 11. At a third of these 15 houses, the number of brethren had declined between 1534 and 1536, though in three cases only by one. For three houses, the number of personnel was the same, and in only one case, St Sepulchre, Warwick, does the number of canons appear to have increased (from two to four). For the priory of Benedictine nuns at Wroxall in Warwickshire, there are of course no signatures for 1534 .

While evidence summarised in Tables 10 and 11 may well support the view that there was a notable decline in recruitment to monastic orders in the second half of the 1530s, it is worth noting that a number of other factors will have affected these figures. First, for those smaller houses suppressed in 1536, only the superior was eligible for a pension. For the Diocese of Worcester, this included the priories of Little Malvern, Studley and Warwick St Sepulchre. Second, for cathedral priories that continued as secular cathedral chapters and those abbeys that became new cathedrals in 1540 and later, it was not uncommon for some of the former monastic brethren to be retained, in the short term or permanently, as canons of the secular cathedrals. These men would not necessarily have been assigned pensions. Thus, for Worcester Cathedral Priory, I have shown elsewhere that the monastic community had not decreased from 41 monks in 1534 to a mere 18 by 1540, as the pension lists would appear to suggest, but had in fact declined to only 36 at the time of the priory's surrender. ${ }^{48}$ The same may well explain in part the apparent fall in numbers at St Peter's Abbey Gloucester and St Augustine's Bristol, which both became cathedrals after their dissolution.

This conclusion about cathedral priories should therefore encourage caution when drawing upon the various sources describing monastic pensions, which in turn should encourage us to examine in more detail the completeness of the supremacy and surrender sources. For St Peter's Abbey, Gloucester, the abbot and 35 monks acknowledged the royal supremacy on 31 August $1534 .^{49}$ Later pension lists for the abbey mention only 14 former inmates, ${ }^{50}$ but a codex at TNA which contains certificates of the commissioners to take the surrender of religious houses in various counties in 1539/40 gives 27 names for the abbey. ${ }^{51}$ What is interesting is that among these 27 monks are a number who are not recorded acknowledging the supremacy but for whom there is independent evidence that they had been monks of Gloucester before 1534. These include Thomas Baskerville, who had been ordained in 1516; John Green, who was subcellerar in 1514; John Hagbourne, ordained in 1523/4; Thomas Hampton, ordained in 1533; Thomas Hartland, ordained in 1505/6; and

\footnotetext{
${ }^{48}$ David E. Thornton, 'The Last Monks of Worcester Cathedral Priory', in Midland History, xliii, 2018, pp. 3-21.

${ }^{49}$ TNA, E 25/58/1.

${ }^{50}$ TNA, E 315/245, f. 97; E 315/234, ff. 137r-140r; E 101/76/27.

${ }^{51}$ TNA, E 315/494/1, ff. 94-5.
} 
Thomas Seabroke, ordained 1509/10. ${ }^{52}$ Unless all of these men had namesakes, then clearly the list of signatures added to the Oath of Supremacy in TNA, E 25/58/1, was incomplete. In at least two cases, the monk in question had been associated with a dependent priory of St Peter's in the 1530s and may therefore have signed an acknowledgment for the relevant priory that has since been lost. ${ }^{53}$ Indeed, association with a cell has been noted by others as a possible factor in underestimating numbers at the mother house. ${ }^{54}$ Furthermore, Thomas Hampton was a student at Oxford at the time of the Dissolution, and may not have actually been at Gloucester in person in August 1534. Evidently, we should not expect the signatures on the surviving documents in TNA series E 25 to be necessarily complete.

If, as this evidence would suggest, the extant documents in series E 25 do not necessarily give a complete and accurate account of the personnel of their respective monasteries in 1534, what can we determine about the completeness and accuracy of the later deeds of surrender and pension lists? Here we must look beyond the Diocese of Worcester. For example, of the 115 monasteries and nunneries with extant E 322 surrender deeds that were dissolved during the final 'voluntary' phase and for which I have to date been able to find pensions lists, 52\% (n = 60) had exactly the same number of brethren in the surrender and pension lists, which means that $48 \%$ record different numbers of religious. About a third of the houses experienced an apparent decrease in the size of their communities in the relevant pension list(s) and a small number show an increase $(17=15 \%)$. An increase in numbers from the time of the surrender of a religious house and the formal recording of pensions to its former monks, canons or nuns a few weeks later would imply that not all religious personnel had signed the deed of surrender. For example, the Benedictine abbey of St Albans was surrendered on 5 December 1539 and the deed was signed by the abbot and 38 monks. ${ }^{55}$ However, the enrolled warrants for pensions dated 14 December record 40 names. ${ }^{56}$ Similarly, 11 Augustinian canons at Haughmond, Shropshire, signed the deed of surrender on 9 September 1539, but the pensions for an additional two canons (William Rolff and Richard Doone) are recorded in E 315/234, dated 2 December $1539 .{ }^{57}$

\footnotetext{
${ }^{52}$ Worcester RO (The Hive), MS b706.093-BA2648/7(ii), p. 174; WRO, MS b706.093-BA2648/8(i), 291, 294, 301, 306, 330; WRO, MS b706.093-BA2648/9(i), 182; Gloucester, Cathedral Library, Register Malvern i (D), ff. 2v-46; Registrum Caroli Bothe, Episcopi Herefordensis, A.D. MDXVIMDXXXV, ed. A.T. Bannister (Canterbury and York Society, xxviii, 1921), 316.

${ }^{53}$ Thomas Seabroke was at Bromfield Priory by c.1534, and Thomas Baskerville was at St Guthlac's Priory, Hereford, by 1538: David M. Smith, The Heads of Religious Houses: England \& Wales, III. 1377-1540 (Cambridge, 2008), 100; A.B. Emden, A Biographical Register of the University of Oxford, A.D. 1501-1540 (Oxford, 1974), 511; Faculty Office Register 1534-1549, ed. D.S. Chambers (Oxford, 1966), 158. In addition, in 1510 John Green had been at the cell at Stanley St Leonards and John Hartland at St Guthlac's, though both men can be associated with the mother house subsequently: Gloucester, Cathedral Library, Register 1510 (C), ff. 2r-36r.

${ }^{54}$ For example, R.B. Dobson, Durham Priory 1400-1450 (Cambridge, 1970), 52-6.

${ }_{55}$ TNA, E 322/208; Hunter, 'The Old Catalogue,' 39.

${ }^{56}$ TNA, E 315/234, LP, xv, no. 1032 (547).

57 TNA, E 322/95A; LP, xv, no. 1032 (547).
} 
Most increases in size are normally restricted to one or two names, as at St Albans and Haughmond. A few increases appear to have been greater, however. For the Gilbertine double-house at Watton, Yorkshire, the priory was surrendered on 9 December 1539 by eight canons as well as Robert Holgate, who was 'commendatory' prior, bishop of Llandaff and master of the order, and also by 14 nuns. ${ }^{58}$ However, pension lists for Watton, dated variously 9 December, 11 December and 12 March 1540, all record the same eight canons but also two prioresses and 30 nuns plus nine lay sisters. ${ }^{59}$ Watton was indeed a sizeable house, with more than 60 nuns in the late fourteenth century, so 32 female religious at the time of the Dissolution is not unreasonable. Clearly in this case, not all the nuns had signed the deed of surrender. On the other hand, apparent increases in numbers at some charterhouses between their surrender and the pension lists may be readily explained: increases at Beauvale from eight to 11, at Hinton from 17 to 23 and at Witham from 13 to 15 can be accounted for by the inclusion among the pensioners of lay brothers, who had not signed the deed of surrender. ${ }^{60}$ The only significant omission is that of Nicholas Dugmer, monk of Beauvale, from the deed of surrender of that charterhouse.

More common, as we have already seen above at Pershore, Gloucester and Worcester, were apparent decreases in numbers between the date of the deed of surrender and the records of monastic pensions. Again, such decreases are usually minimal, but occasionally are more substantial. Table 12 gives the names of 21 monks of the Cistercian abbey at Beaulieu, at the time of its surrender on 2 April 1538. A month later, on 6 May, however, we find only 18 named pensioners and, on the previous day, the same 18 men received dispensations to change habit and hold a benefice according to the Faculty Office Register. ${ }^{61}$

Warrants for monastic pensions stated explicitly that a pension had been assigned for the term of the life of pensioner or until when (quousque) he might receive an ecclesiastical benefice of equal value to the pension, or of more value. The case of former monks of cathedral priories who continued there as secular canons, as at Worcester, has already been cited..$^{62}$ Perhaps during the intervening four weeks after surrendering their abbey, these three ex-monks of Beaulieu had similarly found preferment and were no longer eligible for pensions. Such an explanation could not be used, however, to account for evident decreases in numbers at former female

\footnotetext{
58 TNA, E 322/255; Hunter, 'The Old Catalogue,' 47.

${ }^{59}$ LP, xiv/ii, no. 663; TNA, E 314/53; E 101/76/28-9.

${ }^{60}$ TNA, E 322/18, /99, /270; E 101/76/28; E 315/233, ff. 242r, 263v; E 315/234, f. 53v; Hunter, 'The Old Catalogue,' 9, 23, 50; LP, xv, no. 1032 (pp. 543-4, 546).

${ }^{61}$ TNA, E 322/17; E 315/232; Faculty Office Register, 131.

${ }^{62}$ Indeed, two TNA documents that have come to my attention since publishing the article about the last monks of Worcester explicitly state that six former monks had been initially retained at the cathedral and were only assigned pensions subsequently when they were no longer needed: 'who at the tyme of the surrendre of the same were appointed to remayn and abide in the said late mon' to be of the nombre of the kinges graces newe ffoundacion there, and nowe by the kinges graces appointtment they and eny of theym are and ben appointted to departe the said howse and to have these yerely pencions duryng ther lyeffes' (TNA, E 314/53).
} 
Table 12: Monks of Beaulieu, 1538 (order of names according to deed of surrender).

\begin{tabular}{lll}
\hline Surrender & Pension & Faculty Office Register \\
\hline Thomas, prior & Thomas Stephens & Thomas Stephens \\
Griffith Hampton & Griffith Hampton & Griffith Hampton \\
Thomas Ydle & Thomas Seale & Thomas Seall \\
Richard Frye & Richard Gilford & Richard Guyldford \\
William Coventry & William Coventry & William Coventry \\
Walter Parthalo & Walter Bartolomew & Walter Bartolomew \\
John Kyry & John Kerre & John Bere \\
William Baytrley & William Baskerley & William Baskerley \\
Harmon Hampton & Harmon Hampton & Harmon Hampton \\
Alexander Alyn & Alexander Aleyn & Alexander Alen \\
Robert Pyngleston & Robert Pykton & Robert Pyckton \\
Thomas Whyett & Thomas Whyte & Thomas White \\
Simon Hacker & Simon Hawlker & Simon Halker \\
Thomas Galby & Thomas Ewalbie & Thomas Evaw \\
John Summerfield & John Summerfield & John Summerfield \\
Thomas Burton & Thomas Burton & Thomas Burton \\
Laurence Parker & Laurence Parker & Laurence Parker \\
William Austen & & \\
Roger Dorchier & & \\
Robert Newton & Richard Curlewe & \\
Richard Curlew & &
\end{tabular}

religious houses. Table 13 summarises the evidence for Tarrant Kaines, a house of Cistercian nuns, which was surrendered by the abbess and 19 nuns on 13 March 1539; 16 nuns are recorded as receiving pensions on 23 May 1539. ${ }^{63}$

It might be worth noting that for both Beaulieu and Tarrant Kaines, the names missing from the pension lists occur towards the end of the sequence of signatures on the relevant deeds of surrender. This pattern would suggest that the monks and nuns in question were relatively junior members of their respective communities. Indeed, the warrants for pensions state explicitly that the individually named grantee of the pension had been a religious of his/her house not only at the time of its dissolution but also 'long before' (diu antea). Cardinal Gasquet accordingly took this phrase to mean that very recently admitted religious were not necessarily

${ }^{63}$ TNA, E 322/233; E 315/233, f. 307v; LP, xv, no. 1032 (p. 545). 
Table 13: Nuns of Tarrant Kaines, 1539 (order of names according to deed of surrender).

\begin{tabular}{ll}
\hline Surrender & Pension \\
\hline Margaret Russell, abbess & Margaret Russell \\
Margaret Dalalyne, & Margaret Lyne \\
subprioress & \\
Elizabeth Worsley & Elizabeth Worsley \\
Edith Rawlins & Edith Rawlins \\
Elizabeth Strowed & Elizabeth Strownede \\
Joan Molens & Joan Mollens \\
Mary Newborough & Mary Newborough \\
Alice Parker & Alice Parker \\
Alice Hart & Alice Herte \\
Dorothy Siddenham & Dorothy Sidenham \\
Joan More & Joan More \\
Eleanor Michell & Elena Michell \\
Elizabeth Morton & Elizabeth Morton \\
Joan Balner & Joan Balner \\
Anne Gawen & Anne Gawen \\
Elizabeth Holwall & \\
Elizabeth Dydmyll & \\
Mary Bragge & \\
Elizabeth Smyth & \\
Anne Cheverall & \\
\hline
\end{tabular}

guaranteed pensions. ${ }^{64}$ The length of time understood by the reference 'long before' is not clear. Thus, for example, John Stonely, Cistercian monk of Kingswood, Gloucestershire, is named last in the deed of surrender dated 1 February 1538, and is said to have been a novice in the pension list from the following month and was accordingly assigned a modest pension. ${ }^{65}$ Similarly, Robert Burdus, Augustinian canon of Bolton, Yorkshire, and Thomas Capron alias Skegby, monk of Rievaulx, were subdeacons at the time of the surrender of their respective houses, but both were granted pensions. ${ }^{66}$ Further, detailed study would be necessary to determine whether very recently admitted members of religious communities were usually not assigned pensions.

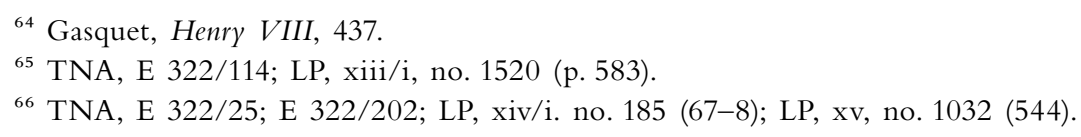




\section{The former religious after the Dissolution}

Although beyond the direct scope of this paper, it should be noted that, in addition to the later pension lists, various other types of document - many housed at TNA - allow us to trace the fate of some former monks and regular canons after the dissolution of their monasteries. Many male ex-religious went on to hold positions in the Church, as secular priests and further up the ecclesiastical hierarchy. Thus, for example, I have been able to trace the subsequent careers of a number of the former monks of Worcester Cathedral Priory as prebendary canons of the new cathedral chapter or holding ecclesiastical livings elsewhere. ${ }^{67}$ Some former religious had become chantry priests and so reappear in the documentation arising from the dissolution of the chantries in the later 1540s.$^{68}$ Thus Gilbert Gybbyns, stipendiary priest of Tenbury, Worcestershire, in 1546 (when he was 60 years old) and 1548, could be identified tentatively as the monk of the same name from Pershore Abbey, who was infirmarer at the time of the abbey's dissolution. ${ }^{69}$ Table 8 above suggests in turn that this monk had borne the monastic byname Abberton in 1534, when he held the office of cook (coquinarius). This Gilbert Abberton had been ordained as monk of Pershore in 1507-11. ${ }^{70}$ Many ex-monks and canons, and some nuns, no longer bound by any vows of poverty, left wills, especially the former superiors, which often survive in the TNA series PROB as well as in other archival locations. ${ }^{71}$ The main problem with identifying the wills of former religious is that the testators rarely indicate their previous status explicitly. Obviously simply being a 'clerk' or priest is insufficient to indicate an ex-monk or canon, but occasionally clues may be found. For example, the will of the priest Thomas Bisley, dated 19 August 1540, states that he was also subwarden of the 'King's College of Gloucester'. ${ }^{72}$ This means that he was a member of the community of stipendiary priests that had replaced the Benedictine monastery of St Peter's, Gloucester, dissolved only seven months earlier, prior to the founding of the new secular cathedral in $1541 .^{73}$ There had been a monk of St Peter's also called Thomas Bisley, who had probably joined the abbey in the late 1490s and was prior of the dependent cell of St Guthlac's, Hereford, at

\footnotetext{
${ }^{67}$ Thornton, 'The Last Monks,' 18-21. The main source of information are episcopal registers, conveniently collected for the CCEd: Clergy of the Church of England Database 1540-1835: http:// theclergydatabase.org.uk/ (accessed 7 June 2019).

${ }^{68}$ In particular, see the paper by Sylvia Gill, “"For the honour of God and the Weal of His Majesty's Realm ...": Reformation Stories from Documents in The National Archives', in this volume of Archives; and her unpublished dissertation, 'Managing Change in the English Reformation: The 1548 Dissolution of the Chantries and Clergy of the Midland County Surveys' (University of Birmingham Ph.D. thesis, 2010).

${ }^{69}$ TNA, E 301/60; E 101/76/7; also Gill, 'Managing Change', 160.

${ }^{70}$ WRO, b706.093-BA2648/8(i), 296-7, 308.

${ }^{71}$ Heale, The Abbots and Priors, 360-73.

${ }^{72}$ TNA, PROB 11/28/221.

${ }^{73} \mathrm{He}$ is not, however, mentioned in a list of priests of the college in Bishops Bell's 'Visitation Book': WRO, 802.BA2764, p. 188.
} 
the Dissolution ${ }^{74}$ and it seems highly likely that these were one and the same man. Furthermore, Bisley made bequests not only to the college and its priests in general, but also specifically to 'Bachelor Bowes', who may be Hugh Bowles, bachelor of theology, another former Gloucester monk, and he named as his executors Thomas Seabroke and Edward Bennet, both priests and also former monks. ${ }^{75}$ The will was proved on 27 September 1540, demonstrating that Thomas Bisley survived his former monastery by less than a year. Other former religious were to last longer, as attested by their wills. The aforementioned Gilbert Gybbyns, ex-monk of Pershore, for instance, drew up his last will and testament in April 1558, by which time he was priest at Peopleton, Worcestershire. ${ }^{76}$

\section{The current state of research and publication}

The foregoing evidence would suggest that many of the documents at TNA examined for this paper do not always preserve a complete or accurate record of the numbers and personnel of monasteries in 1534 and later at the Dissolution. For as full an account of monastic communities in the late 1530s as possible, it is necessary, therefore, to consult all available documentation, whether printed or yet unpublished. This brings us to a final consideration of the accessibility of the sources: many remain unpublished or, if they have appeared in print - usually in the form of a calendared description rather than full text - the relevant edition or calendars are old and often out of date. Thus transcriptions of the signatures of the acknowledgments of the royal supremacy in E 25 and of the deeds of surrender in E 322, printed without the accompanying main text, were published over a century and a half ago in the Seventh and Eighth Annual Reports of the Deputy Keeper of the (then) Public Record Office respectively.

Admittedly, the recent digitisation of out-of-print books and journals means that both are readily available online for free, unlike 20 years ago when scholars would have been reliant on finding the annual reports in a library or archive. However, editorial principles, not to mention TNA cataloguing, have moved on since the 1840s: for example, the use of record-type abbreviation conventions renders these two calendar editions somewhat archaic and cumbersome to use. Furthermore, many documents relating to monastic pensions remain unpublished in any form or, at best, have appeared partially in local studies of individual monasteries. Some were calendared in Letters and Papers, Foreign and Domestic, of the Reign of Henry VIII, which was also published over a hundred years ago: these are occasionally presented as a self-contained section of the calendar derived from a single source; but in other cases the pension lists for individual religious houses are scattered chronologically through the calendar. The volumes of Letters and Papers have been digitised online

\footnotetext{
${ }^{74}$ TNA, E 315/494/1, ff. 94-5; Faculty Office Register, 158.

75 TNA, E 25/58/1; Devon, 'Inventory', 287; Faculty Office Register, 158; E 315/494/1, ff. 94-5;

E $164 / 31$.

${ }^{76}$ WRO, b008.7BA3950/2, f. 719 .
} 
and they also appear in html format on the British History Online (BHO) website. ${ }^{77}$ For those historians whose libraries have an institutional subscription to the State Papers Online database, manuscript images of many, but not all, of the original documents calendared in Letters and Papers can be viewed online. In addition, TNA's online catalogue goes some way to locating documents relating to monastic pensions, though the series descriptions currently accessible only in paper format at TNA are more detailed and useful. Lastly, it is worth noting that these calendars and editions are not always free from error when reproducing the names of signatories or pensioners. Names in manuscripts are notoriously problematic for editors, of course, and especially so for E 25 and E 322 where we are dealing with multiple signatures in different hands. For instance, the tenth signature in 1534 for St Peter's Abbey, Gloucester, was not Clementus Meetit (admittedly accompanied by a question mark in the calendar), but may be identified as Edmundus Wotone (Wotton); and, slightly less confusing, his confrere Edwardus Broucot was in fact surnamed Benet and was to be the executor of the will of Thomas Bisley, discussed above. ${ }^{78}$ Similar errors no doubt occur in the editions and calendars of the surrenders and pension lists, and make the task of identifying the individuals in question all the more difficult. Indeed, in the light of such editorial mistakes, as well as the overall significance of these documents, it is high time for new editions and fresh study.

For the historian interested in the prosopography of monasticism in late medieval and early Tudor England and Wales, there is no doubt that TNA houses an unrivalled collection of important archival sources. However, as we have seen, the nature of these sources, and their interpretation, are far from straightforward. Two of the TNA series discussed in this paper (E 25 and E 322) are certainly incomplete: the oaths and surrender deeds of many monasteries are now lost. Even for those that do survive, there is the difficulty of interpretation because, at the Dissolution, many former religious resumed using their family surnames. Furthermore, despite strong evidence for a general reduction in the size of monastic communities, due partly to departures from religion and an apparent decline in recruitment, it is evident that the relevant surviving documents may not always represent a complete record and the evidence certainly requires careful scrutiny. Finally, in addition to the fact that many documents in TNA pertinent to this paper have not yet been published, those that have are certainly in need of fresh scholarly attention.

\footnotetext{
77 See https://www.british-history.ac.uk/search/series/letters-papers-hen8 (accessed 7 June 2019).

${ }^{78}$ TNA, E 25/58/1; Devon, 'Inventory,' 287.
} 